\title{
Weed communities of root crops in the Pamir Alai Mts, Tajikistan (Middle Asia)
}

\author{
Sylwia Nowak, Arkadiusz Sebastian Nowak* \\ Department of Biosystematics, Opole University, Oleska 22, 45-052 Opole, Poland
}

\section{Abstract}

The paper presents the results of investigations of weed vegetation conducted on root crops in Tajikistan (Middle Asia), one of the world cradles of weed flora. The main research was conducted in the Zeravshanian, southern Tajikistan and Hissar-Darvasian geobotanical regions in 2011. The study was based on 107 phytosociological relevés obtained in various geobotanical regions of the country. The collected material probably presents the majority of variations among the weed communities of root cultivations in the Middle Asia. As a result of numerical analyses, 7 associations were distinguished: Convolvulo arvensis-Cyperetum rotundi, Daturo stramonii-Hibiscetum trioni, Setario pumilae-Sorghetum halepensi, Galinsogo-Setarietum, Equiseto arvensi-Xanthietum italici, Portulacetum oleracei and Brassico campestris-Lamietum amplexicauli. The last mentioned is new to science. Additionally, one subassociation has been proposed (Convolvulo arvensis-Cyperetum rotundi kochietosum scopariae). The main discrimination factor for the data set is the floristic structure of the associations. The study shows that root-crop plantations with segetal vegetation may harbor a relatively rich flora. Almost 200 species were found in vegetation plots, including some, which are rare and have not been recorded until now in this part of Middle Asia. However, most of the recorded species are widespread weeds typical for the Mediterranean and Irano-Turanian geobotanical provinces.

Keywords: Stellarietea mediae, Atriplici-Chenopodietalia, agrocoenoses, segetal communities, Tadzhikistan

\section{Introduction}

According to the ten-volume flora of the former Soviet Socialist Republic of Tajikistan [1-8], supplemented by the works of Zakirov [9], Tzvelev [10], and Ikonnikov [11], ca. 4550 vascular plant species occur in Tajikistan. This number is not final, as recently some new records regarding the Tajik flora have been published (e.g. [12-17]). Moreover, some species new to science have been described based on plant specimens collected in the general area of this country (e.g. [18-25]). Tajik vascular plant flora is considered as among the richest in the area of the former Soviet Union. This area is also recognized as one of the most important centers of weed species in the world [26]. Approximately $30 \%$ of vascular plant species known from Tajikistan are generally accepted endemics of the country $[8,27,28]$. It is worth mentioning that the Pamir-Alai range is part of the middle Asian mountain system recognized by Conservation International to be among thirty-four so-called

* Corresponding author. Email: anowak@uni.opole.pl

Handling Editor: Łukasz Łuczaj

This is an Open Access digital version of the article distributed under the terms of the Creative Commons Attribution 3.0 License (creativecommons.org/licenses/by/3.0/), which permits redistribution, commercial and non-commercial, provided that the article is properly cited. hotspots of biodiversity [29] and as one of the eleven most important focal points of future plant diversity studies and conservation [30]. On the other hand, having the near-lowest adaptive capacity to climate instability, Tajikistan is regarded as the country most sensitive in the world to climate change [31]. According to Baettig et al. [32], it is exposed to a high risk of climate change, which is going to be one of the most important degradation factors for the vegetation cover of the country.

Recent syntaxonomical studies of segetal communities have been carried out for several years now in many regions of the world, mainly in countries of Central Europe (e.g. [33-39]) and Asia [40-42]. For several regions similar in terms of climatic conditions (the Mediterranean and Irano-Turanian geobotanical provinces) useful data regarding field communities are available, e.g. for Afghanistan, Serbia, Italy, Greece, Romania, Bulgaria, and Spain [43-50]. There is little data from the Saharo-Sindian province, where numerous weed species ranging as far as Tajikistan in the east originate [51-53]. Unfortunately, to date, in some regions of Central Asia, for example in Kyrgyzstan, Kazakhstan, or Uzbekistan, no research on the plant communities of these field ecosystems has been conducted. This applies to cereal as well as root crops.

Research on agrocoenoses has been carried out across the globe, within a range of contexts and with different levels of intensiveness. Recently, a large number of papers have documented the problem of maintaining conservation values for agrocoenoses in relation to the intensification of crop production. In Europe as well as in Asia, for cereal and root crops, a decrease in biodiversity has been noted, as exemplified by the 
abandonment of unprofitable crops (especially in middle and higher mountain elevations) and intensification of the production of others [54-60].

In some regions of the world, relationships between the richness of vegetation patches and various abiotic factors, as well as the abundance of weed flora in crop communities, e.g. altitude, soil type, climate, etc., have been relatively well studied [61-65].

A number of studies have appeared recently, which record basic floristic and vegetation data for root crops or cereals, often focusing on their special role for the protection of threatened or endemic species [66-70]. As well, vanishing and rare species, and communities related to agricultural land and weed habitats other than agrocoenoses, have been a center of attention for botanists in recent years [58,71-76]. Additionally, changes in segetal flora over the years have been analyzed (e.g. [77]). The growing interest in endangered weed species is the reason for the first conservation projects involving extinct or disappearing taxa (e.g. [78]). Specific biological features, which are probably responsible for weed regression (e.g. [79]) or expansion (e.g. [80]) have received less attention. Therefore, it is nearly incomprehensible that within one of the world's cradles of weeds, virtually no conservation research focused on weed flora has been conducted.

Phytosociological research is essential in order to document the syntaxonomic diversity of weed phytocoenoses. Unfortunately, only a few works focused on vegetation classification have been issued recently [81-83]. They are all the more important because so far there have been no syntaxonomic works on segetal communities published on this country, even though the vegetation is so rich and relatively well preserved due to the low intensity of cultivation. Outside Middle Asia, segetal weed vegetation studies have been conducted for a few areas situated a bit further within the region, e.g. Bashkortostan (southern Urals) and Mongolia in Central Asia [41,42,84].

\section{Material and methods}

\section{Study area}

Tajikistan covers $143500 \mathrm{~km}^{2}$ and is situated in the Middle Asia between E $36^{\circ} 40^{\prime}-41^{\circ} 05^{\prime}$ and $\mathrm{N} 67^{\circ} 31^{\prime}-75^{\circ} 14^{\prime}$ (Fig. 1). This is a typically mountainous country, with more than $50 \%$ of the area located above $3000 \mathrm{~m}$. The southern part of Tajikistan is influenced by a subtropical climate, while the northern part is situated in the temperate climate zone [85]. Generally, the country is characterized by high insolation, a low percentage of cloud cover, high amplitude of annual temperatures, low humidity and low precipitation. In subtropical regions of Tajikistan, the average temperatures in June are around $30^{\circ} \mathrm{C}$. In the temperate zone, which in Tajikistan comprises mainly the high mountains, the climate is much harsher, with average temperatures in July between $9.7^{\circ} \mathrm{C}$ and $13.5^{\circ} \mathrm{C}$. Annual precipitation in Tajikistan ranges from ca. $70 \mathrm{~mm}$ (in the Pamirs) to ca. $600 \mathrm{~mm}$ (in the Hissar Range). The lower limit of perpetual snow is at an altitude of 3500-3600 meters above sea level in the western part of the country, $5800 \mathrm{~m}$ in the eastern regions (Fig. 2) [86,87]. The cultivation zones are distributed in accordance with the perpetual snow cover, from ca. $350-3300$ $\mathrm{m}$ in western Tajikistan up to about $4800 \mathrm{~m}$ in eastern Pamir.

This study was conducted in the northern, northwestern, southwestern and southeastern parts of Tajikistan, mainly in the valleys of the Syr Darya, Amu Darya, Pyandzh, Veshan,

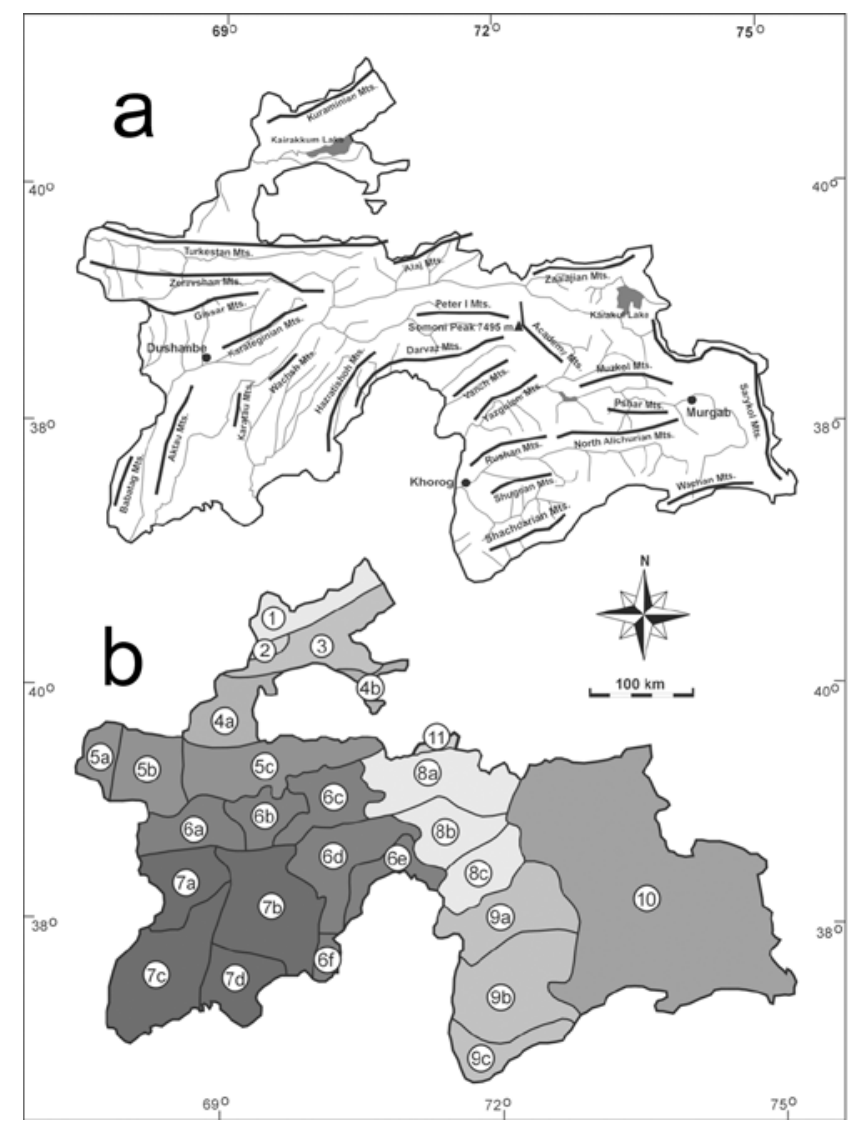

Fig. 1 a The area of Tajikistan with main cities, mountain ridges, rivers and lakes. $\mathbf{b}$ The geobotanical division of Tajikistan: 1 - Kuraminian; 2 - Mogoltausian; 3 - Prisyrdarian; 4a - Turkestanian A; $4 \mathrm{~b}$ - Turkestanian B; 5a - Zeravshanian A; 5b - Zeravshanian B; 5c - Zeravshanian C; 6a - Hissar-Darvasian A; 6b - Hissar-Darvasian B; 6c - Hissar-Darvasian C; 6d - Hissar-Darvasian D; 6e - HissarDarvasian E; 6f - Hissar-Darvasian F; 7a - South Tajikistanian A; 7b - South Tajikistanian B; 7c - South Tajikistanian C; 7d - South Tajikistanian D; 8a - East Tajikistanian A; 8b - East Tajikistanian B; 8c - East Tajikistanian C; 9a - West Pamirian A; 9b - West Pamirian B; 9c - West Pamirian C; 10 - East Pamirian; 11 - Alajian.

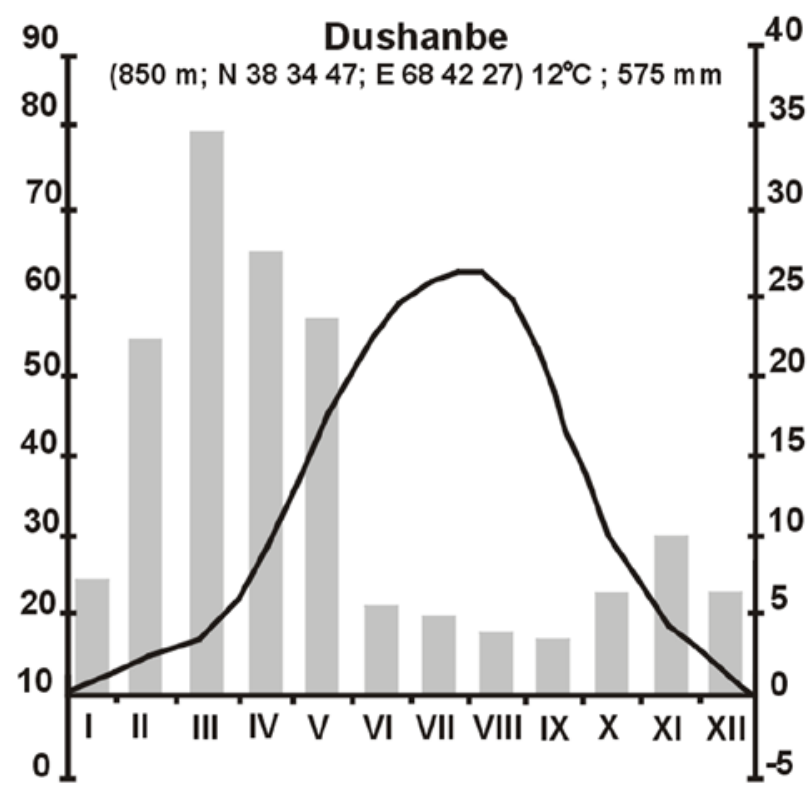

Fig. 2 Climatic characterisation of the study area according to the Dushanbe weather station. 
Vakhsh, Zeravshan, Kafirnighan, Khanaka and Surkhan Darya Rivers, where vast areas of root cultivations are concentrated. The studied vegetation patches are located between 344 and 2615 meters above sea level. They are developed on different types of substrate, with a range of soil $\mathrm{pH}$ between 6.8 to 7.9, and containing various granulometric structures.

\section{Data and analyses}

The field study was conducted in 2011. During the study 107 phytosociological relevés were made. The plot size used to sample vegetation was established so as to represent full floristic composition, varying from 25 to $30 \mathrm{~m}^{2}$ depending on plant density and homogeneity of vegetation cover. For each vegetation patch all vascular plants were recorded. Cryptogams were not noted because of their secondary importance in the segetal communities in the Middle Asia. Plant species were recorded according to the Braun-Blanquet cover-abundance scale [88]. Geographical coordinates, elevation above sea level, aspect and slope inclination were noted for each relevé.

All relevés were stored in a database using the JUICE software [89]. A TWINSPAN analysis [90] was used to perform the preliminary classification of communities. The data from the relevés showed a clear unimodal response, enabling us to use a detrended correspondence analysis (DCA) with a floristic data set (presence-absence data, no down weighting of rare species) to check floristic-sociological classification and to show relationships between the groups. For ordination, CANOCO for Windows 4.5 was used [91].

Vegetation classification follows the sorted table approach of Braun-Blanquet [88]. In the analytic tables (Tab. S1, Tab. S2, Tab. 1-Tab. 3), species constancies are given in classes I-V [92]. In cases where a particular species was noted in less than 8 relevés, the absolute number of species occurrences was specified. Newly presented syntaxa described as associations or subassociations were proposed according to the international code of phytosociological nomenclature [93]. In distinguishing a given association, the works of Sîrbu [94], Brullo et al. [45], Matuszkiewicz [37], Šilc \& Čarni [38], Sanda et al. [47], Chytrý [95], Tzonev et al. [50], Bagrikova [96], Ninot et al. [97] and Wittig et al. [53] were taken into account. The association concept follows Willner [98]. The presented communities are arranged into a syntaxonomic overview at the end of the "Results" section.

Species nomenclature mainly followed Czerepanov [99]. Plant material collected during field studies was deposited in the Herbarium of Middle Asian Mountains, hosted in OPUN (Opole University, Poland) and KRA (Jagiellonian University, Poland).

\section{Results}

The number of taxa recorded in the relevés totals 182 , of which 59 exceed 5\% constancy and 36 exceed 10\%. The species with the highest frequencies include: Convolvulus arvensis (80 occurrences), Chenopodium album (68), Cyperus rotundus (62), Portulaca oleracea (47), Xanthium italicum (45), Echinochloa crus-galli (43), Amaranthus retroflexus (42), Cynodon dactylon (40), Polygonum aviculare (37), Sonchus oleraceus and Sorghum halepense (34), Hibiscus trionum (32), Setaria viridis (31), Setaria pumila and Lamium amplexicaule (25). Not all of the species noted in relevés are typical of root crop vegetation. In the studied phytocoenoses, species typical for cereal crop
Tab. 1 Galinsogo-Setarietum.

\begin{tabular}{|c|c|c|c|c|c|c|c|}
\hline Successive number of relevé & 1 & 2 & 3 & 4 & 5 & 6 & 7 \\
\hline Day & 2 & 17 & 2 & 2 & 2 & 2 & 2 \\
\hline Month & 6 & 6 & 6 & 6 & 6 & 6 & 6 \\
\hline Year & 2011 & 2011 & 2011 & 2011 & 2011 & 2011 & 2011 \\
\hline Altitude (m) & 1254 & 1021 & 1254 & 1180 & 1158 & 1254 & 1158 \\
\hline Cover of herb layer (\%) & 50 & 40 & 20 & 35 & 40 & 40 & 35 \\
\hline Relevé area $\left(\mathbf{m}^{2}\right)$ & 30 & 30 & 30 & 30 & 30 & 30 & 30 \\
\hline pH & 7.2 & 7.2 & 7 & 7 & 7 & 6.8 & 6.9 \\
\hline Number of weeds & 10 & 16 & 16 & 14 & 14 & 10 & 13 \\
\hline
\end{tabular}

\begin{tabular}{|c|c|c|c|c|c|c|c|}
\hline \multicolumn{8}{|c|}{ Cultivated plants } \\
\hline Solanum tuberosum & . & . & . & 4 & 3 & 3 & 4 \\
\hline Allium porrum & . & 2 & . & . & . & . & \\
\hline Citrullus lanatus & . & + & . & . & . & - & . \\
\hline Cucumis sativus & 3 & . & . & . & . & . & \\
\hline Daucus carota & . & . & 5 & . & . & . & \\
\hline
\end{tabular}

\section{Diagnostic species}

\section{Ass. Galinsogo-Setarietum}

Galinsoga parviflora

Galinsoga ciliata

$\begin{array}{rrrrrrrr}2 & 2 & 1 & 2 & 3 & 3 & 3 & 7 \\ + & + & + & + & . & . & . & 4\end{array}$

\section{All. Oxalidion fontanae}

Oxalis fontana

Sonchus oleraceus

Veronica persica

$\begin{array}{llllllll}\cdot & \cdot & \cdot & \cdot & \cdot & \cdot & \cdot & \\ + & + & + & + & 1 & 1 & + & 7 \\ \cdot & + & \cdot & 1 & + & + & + & 5 \\ . & \cdot & + & 1 & + & . & . & 3\end{array}$

\section{O. Atriplici-Chenopodietalia albi \& Cl. Stellarietea mediae}

$\begin{array}{lccccccccc}\text { Kochia scoparia } & 3 & 2 & 1 & + & + & + & & 6 \\ \text { Polygonum aviculare } & . & + & . & 1 & + & + & + & 5 \\ \text { Polygonum persicaria } & 1 & + & + & . & . & . & + & 4 \\ \text { Setaria pumila } & + & + & + & 1 & & . & . & 4 \\ \text { Sisymbrium altissimum } & . & . & + & + & + & . & + & 4 \\ \text { Chenopodium album } & . & 1 & 1 & + & . & . & . & 3 \\ \text { Spinacia turkestanica } & + & . & . & . & + & . & . & 2\end{array}$

Sporadic species: Amaranthus retroflexus 2; Bromus sterilis 3; Capsella bursa-pastoris 3; Cynodon dactylon 2(1); Cyperus rotundus 2; Fallopia convolvulus 2; Geranium pusillum 3; Portulaca oleracea 2(1); Setaria viridis 2.

\section{Others}

\begin{tabular}{|c|c|c|c|c|c|c|c|}
\hline Trifolium repens & . & . & + & 1 & 1 & 1 & + \\
\hline Taraxacum sp. & + & . & . & + & + & + & + \\
\hline Plantago lanceolata & . & + & + & . & + & + & + \\
\hline Plantago major & . & . & . & + & + & 1 & 1 \\
\hline Poа аппиа & + & . & . & + & + & . & . \\
\hline Trifolium pratense & . & . & 1 & . & . & . & + \\
\hline Anethum graveolens & + & . & . & . & + & . & . \\
\hline Stellaria neglecta & . & . & + & . & . & . & + \\
\hline Isatis tinctoria & . & . & . & . & . & + & + \\
\hline
\end{tabular}

Locality of relevé: 1 - (382728; 704625,5); 2 - (383810; 690840); 3 (382728; 704625,5); 4 - (382728; 704625,5); 5 - (382728; 704625,5); 6 - $(382728 ; 704625,5) ; 7$ - $(382728 ; 704625,5)$.

communities have also been observed: Anthemis altissima, Anagallis foemina, Avena trichophylla, Fagopyrum tataricum, 
Tab. 2 Brassico campestris-Lamietum amplexicauli ass. nova.

\begin{tabular}{|c|c|c|c|c|c|c|c|c|c|c|c|c|c|c|c|c|c|c|}
\hline Successive number of relevé & 1 & 2 & 3 & 4 & 5 & 6 & 7 & 8 & 9 & 10 & 11 & 12 & 13 & 14 & 15 & 16 & 17 & 18 \\
\hline Day & 6 & 4 & 14 & 14 & 5 & 7 & 7 & 13 & 10 & 13 & 13 & 13 & 14 & 15 & 15 & 15 & 8 & 8 \\
\hline Month & 6 & 6 & 6 & 6 & 6 & 6 & 6 & 6 & 5 & 6 & 6 & 6 & 6 & 6 & 6 & 6 & 9 & 9 \\
\hline Year & 2011 & 2011 & 2011 & 2011 & 2011 & 2011 & 2011 & 2011 & 2011 & 2011 & 2011 & 2011 & 2011 & 2011 & 2011 & 2011 & 2011 & 2011 \\
\hline Aspect & - & - & - & - & - & $\mathrm{NE}$ & - & - & - & - & - & - & - & $\mathrm{N}$ & $\mathrm{N}$ & - & - & - \\
\hline Inclination (degrees) & - & - & - & - & - & 3 & - & - & - & - & - & - & - & 15 & 15 & - & - & - \\
\hline Altitude (m) & 1967 & 2182 & 2049 & 2050 & 2615 & 2275 & 2271 & 2018 & 598 & 2020 & 2020 & 1864 & 2384 & 2497 & 2497 & 2450 & 2220 & 2220 \\
\hline Cover of herb layer (\%) & 40 & 50 & 20 & 40 & 20 & 40 & 15 & 30 & 70 & 15 & 25 & 20 & 30 & 50 & 35 & 45 & 45 & 15 \\
\hline Relevé area $\left(\mathrm{m}^{2}\right)$ & 30 & 30 & 30 & 30 & 30 & 30 & 30 & 30 & 30 & 30 & 30 & 30 & 30 & 30 & 30 & 30 & 30 & 30 \\
\hline $\mathrm{pH}$ & 7.1 & 7 & 7 & 7.3 & 7.5 & 7.6 & 7.2 & 7.1 & 7.4 & 7.3 & 7 & 7.3 & 7.1 & 7.3 & 7.1 & 7.5 & 7.5 & 7.5 \\
\hline Number of weeds & 7 & 12 & 12 & 10 & 8 & 5 & 9 & 14 & 17 & 9 & 9 & 13 & 12 & 11 & 11 & 12 & 15 & 13 \\
\hline
\end{tabular}

\section{Cultivated plants}

Solanum tuberosum

Allium cepa

Phaseolus vulgaris

\section{Diagnostic species}

\section{Ass. Brassico campestris-Lamietum amplexicauli}

Lamium amplexicaule

Brassica campestris

$\begin{array}{rllllllllllllllllll}1 & 1 & 1 & 1 & 1 & + & 1 & 1 & + & + & 1 & + & 2 & 3 & 3 & 1 & 1 & + & \mathrm{V} \\ + & + & + & 1 & 1 & 2 & 1 & 2 & 1 & 1 & 2 & 2 & 1 & 1 & + & 1 & 1 & 1 & \mathrm{~V}\end{array}$

All. Veronico-Euphorbion, O. Atriplici-Chenopodietalia albi \& Cl. Stellarietea mediae

Chenopodium album

Convolvulus arvensis

Capsella bursa-pastoris

Fagopyrum tataricum

Polygonum persicaria

Lycopsis orientalis

Descurainia sophia

Sonchus oleraceus

Sisymbrium altissimum

Lepyrodiclis holosteoides

Lepidium latifolium

Polygonum aviculare

Setaria pumila

Amaranthus blitum

Chenopodium botrys

Asperugo procumbens

Sonchus asper

Malva neglecta

Euphorbia falcata

Fallopia convolvulus

\begin{tabular}{|c|c|c|c|c|c|c|c|c|c|c|c|c|c|c|c|c|c|c|}
\hline & 2 & 1 & 1 & 1 & + & + & + & + & . & + & 1 & 1 & 1 & 1 & 3 & 2 & 1 & $\mathrm{~V}$ \\
\hline . & . & 1 & + & . & 2 & 1 & 1 & 1 & + & . & + & 1 & 1 & . & 1 & + & 1 & IV \\
\hline . & . & . & . & . & . & . & . & + & + & + & + & + & + & . & + & . & . & II \\
\hline . & 1 & . & . & . & . & . & + & . & + & 1 & + & + & . & . & . & . & . & II \\
\hline 1 & 1 & + & 2 & . & . & . & . & . & . & . & . & . & . & . & . & . & . & II \\
\hline . & . & . & + & . & . & . & . & . & . & . & . & + & 1 & . & . & + & . & II \\
\hline . & . & . & + & . & . & . & . & + & . & . & . & . & . & + & 1 & . & . & II \\
\hline 1 & . & . & . & . & . & . & . & + & . & . & + & . & . & . & . & . & . & I \\
\hline . & . & + & . & . & . & . & . & 1 & . & . & . & . & . & + & . & . & . & I \\
\hline . & . & . & . & + & . & . & . & . & . & . & . & . & 1 & + & . & . & . & I \\
\hline . & . & . & . & . & . & . & + & . & 1 & . & . & . & . & . & . & . & + & I \\
\hline . & . & . & . & . & . & + & . & . & . & . & + & . & . & . & + & . & . & I \\
\hline . & . & . & . & . & . & . & . & . & . & . & . & . & . & . & . & 2 & 1 & I \\
\hline . & 2 & . & . & . & . & . & . & . & . & . & + & . & . & . & . & . & . & I \\
\hline . & + & . & . & 1 & . & . & . & . & . & . & . & . & . & . & . & . & . & I \\
\hline . & . & . & . & . & . & + & . & . & . & . & . & . & . & + & . & . & . & I \\
\hline . & . & . & . & . & . & . & . & . & + & + & . & . & . & . & . & . & . & I \\
\hline . & . & . & . & . & . & . & . & . & . & . & + & . & . & . & + & . & . & I \\
\hline . & $\cdot$ & $\cdot$ & · & $\cdot$ & $\cdot$ & $\cdot$ & $\cdot$ & . & . & . & . & . & . & . & . & + & + & I \\
\hline . & . & . & . & . & . & . & . & . & . & . & . & . & . & . & . & + & + & I \\
\hline
\end{tabular}

Sporadic species: Acroptilon repens 14; Chenopodium ficifolium 1(3); Chenopodium murale 18; Chenopodium rubrum 4(2); Conyza canadensis 9; Datura stramonium 12; Eruca sativa 17; Galinsoga parviflora 12; Hordeum leporinum 9(1); Hyoscyamus niger 16; Lathyrus cicera 13(1); Lithospermum arvense 17; Thlaspi arvense 17; Torilis leptophylla 9(2); Vaccaria hispanica 2; Veronica didyma 9(1); Vicia peregrina 12.

Others

Rumex crispus

Medicago sativa

Galium aparine

Arenaria serpyllifolia

Phragmites australis

Melilotus officinalis

Poa pratensis

Carum carvi

Taraxacum sp.

Astragalus tibetanus 
Mentha asiatica

Cichorium intybus

Sporadic species: Achillea millefolium 3; Artemisia absinthium 8; Artemisia persica 18; Artemisia vulgaris 8; Astragalus sp. 5; Barbarea arcuata 9; Bromus popovii 9; Equisetum arvense 3(1); Geranium rotundifolium 11; Lamium album 15; Medicago ×varia 17(1); Phleum graecum 9(1); Poa supina 15; Potentilla orientalis 8; Potentilla supina 3; Trifolium repens 11; Veronica arvensis 9; Veronica rubrifolia 16.

Locality of relevé: 1 - (375739,9; 713158,1); 2 - (371829,2; 713014,9); 3 - (391054,1;684328,7); 4 - (391054,1; 684328,7); 5 - (381834,9; 722842,4); 6 - (390948,2; 684818,2); 7 - (390948,2; 684818,2); 8 - (391401,9; 682546,8); 9 - (411751; 721232,9); 10 - (391401,9; 682546,8); 11 - (391401,9; 682546,8); 12 - (392207,6; 683827,9); 13 - (390256,2; 681914,9); 14 - (391135,1; 690518,5); 15 - (391135,1; 690518,5); 16 - $(391135,1 ; 690518,5)$; 17 - $(390322 ; 682054,8) ; 18$ - $(390322 ; 682054,8)$. Con - constancy.

Galium spurium, Acroptilon repens, Lepyrodiclis holosteoides, Lycopsis orientalis and others. As well, some ruderal species (e.g. Melilotus officinalis, Descurainia sophia, Cichorium intybus, Bromus sterilis, Sisymbrium altissimum, S. loeselii, Galium aparine, Tribulus terrestris) along with plants typical of riverbed vegetation (e.g. Calamagrostis pseudophragmites, Equisetum ramosissimum, Pseudosophora alopecuroides), dry grasslands (e.g. Heliotropium ellipticum, Phleum graecum, Centaurea solstitialis, Filago vulgaris), meadows and pastures (e.g. Trifolium repens, T. pratense, Plantago major, Carum carvi, Poa pratensis) or rushes (e.g. Phragmites australis, Mentha asiatica, Bolboschoenus planiculmis, Rorippa palustris, Polypogon demissus) occur within root crop communities. It is worth noticing that in the relevés obtained in the study area kenophytes (e.g. Galinsoga ciliata, G. parviflora, Conyza canadensis), with the exception of Datura stramonium, were noted rather sporadically.

As a result of the numerical classification of all of the relevés for root crop weed phytocoenoses, 8 groups were distinguished. These groups are identified as 7 associations and 1 community (respectively from the left to right part of the diagram): the Brassico campestris-Lamietum amplexicauli, GalinsogoSetarietum, Convolvulo arvensis-Cyperetum rotundi, Daturo stramonii-Hibiscetum trioni, Equiseto arvensi-Xanthietum italici, Portulacetum oleracei, and Setario pumilae-Sorghetum halepensi associations, and a community with Chrysanthemum coronarium (Fig. 3).

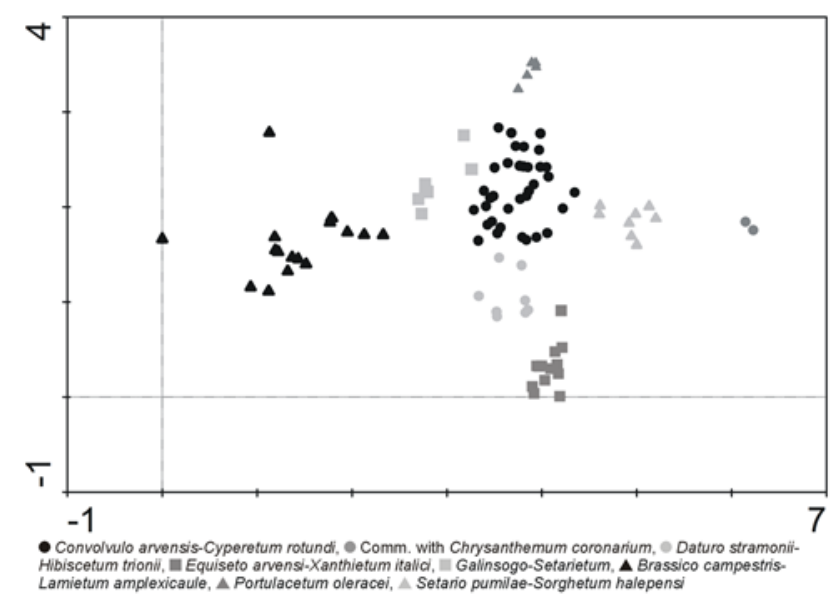

Fig. 3 DCA ordination for all samples of segetal communities $(N=107)$.
The DCA ordination run for the entire data set clearly segregates the association described as new to science (Brassico campestris-Lamietum amplexicauli) as well as other associations. The reason for this is, of course, the essential differences in the floristic composition and structure of individual phytocoenoses. Only plots closely related in terms of habitat conditions, such as some phytocoenoses of Convolvulo-Cyperetum, GalinsogoSetarietum and Daturo-Hibiscetum, are not clearly distinguishable one from another. This is probably due to the irrigation of the fields in which they appear and the occurrence of common species of wet habitats such as Plantago major, Polygonum aviculare and Cyperus rotundus.

\section{Syntaxa of the root crops in Tajikistan}

CONVOLVULO ARVENSIS-CYPERETUM ROTUNDI Carretero et Aguilella ex Ninot, X. Font, Masalles et Vigo 2010-2011 (Tab. S1, rel. 1-39).

Diagnostic species: Cyperus rotundus.

The Convolvulo arvensis-Cyperetum rotundi association is among those particularly common in Tajikistan. Phytocoenoses dominated by, or featuring a high share of, Cyperus rotundus developed mostly in middle sections of alpine rivers of the study areas, among others, the Syr Darya, Pasrud Darya, Yagnob, Zeravshan, Kafirnighan and Vakhsh Rivers, mostly at altitudes of ca. 700-900 m. Convolvulo arvensis-Cyperetum rotundi occurs mainly in maize, potato, tomato, cotton, leek and, rarely, in parsley plantations. The association develops in moist and fertile, brown soils with close to neutral reactions ( $\mathrm{pH}$ approx. 7.3; Fig. 4). Fields are in most cases irrigated. Cyperus rotundus is not always apparently dominant; however, in a few plots, the cover of this diagnostic species exceeds $40 \%$. The mean cover value of Cyperus rotundus is ca. $10-20 \%$. In phytocoenosis, which is relatively rich in species, ca. 14 taxa have been noted on average. Co-occurring species represent mainly the Atriplici-Chenopodietalia albi order and the Stellarietea mediae class, e.g. Echinochloa crus-galli, Chenopodium album, Convolvulus arvensis, Setaria viridis, Amaranthus retroflexus, Sonchus oleraceus, Polygonum aviculare, the Eragrostietalia order, e.g. Portulaca oleracea, Cynodon dactylon and cereal communities, e.g. Avena trichophylla. The phytocoenosis is also supported by species typical for moist ruderal communities such as Polygonum aviculare (Tab. S1). Within Convolvulo arvensisCyperetum rotundi, due to a significant share of Kochia scoparia, the subassociation of $\mathrm{Ca}$-Cr kochietosum scopariae subass. nova has been distinguished (Typus relevé - Tab. S1, rel. 34; locality: 
Tab. 3 Portulacetum oleracei.

\begin{tabular}{|c|c|c|c|c|c|c|}
\hline Successive number of relevé & 1 & 2 & 3 & 4 & 5 & \\
\hline Day & 10 & 30 & 10 & 10 & 7 & \\
\hline Month & 9 & 5 & 9 & 9 & 9 & 8 \\
\hline Year & 2011 & 2011 & 2011 & 2011 & 2011 & Ð \\
\hline Altitude (m) & 950 & 816 & 772 & 850 & 886 & $\bar{J}$ \\
\hline Cover of herb layer (\%) & 65 & 70 & 60 & 40 & 70 & 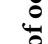 \\
\hline Relevé area $\left(\mathbf{m}^{2}\right)$ & 30 & 30 & 30 & 30 & 30 & \pm \\
\hline pH & 7.2 & 7.2 & 7.4 & 7.5 & 7.2 & $\vec{\Xi}$ \\
\hline Number of weeds & 16 & 14 & 16 & 15 & 10 & $\mathbf{z}$ \\
\hline
\end{tabular}

\begin{tabular}{lccccc}
\multicolumn{5}{c}{ Cultivated plants } \\
\hline Solanum tuberosum & 3 & 3 & 3 & 4 & $\cdot$ \\
Lycopersicon esculentum & $\cdot$ & $\cdot$ & $\cdot$ & $\cdot$ & 3 \\
Citrullus lanatus & $\cdot$ & $\cdot$ & $\cdot$ & $\cdot$ & 1 \\
& & & & & \\
& & & \\
& Diagnostic species
\end{tabular}

Ass. Portulacetum oleracei

$\begin{array}{lllllllll}\text { Portulaca oleracea } & 4 & 4 & 4 & 3 & 4 & 5\end{array}$

All. Eragrostion cilianensi-minoris, O. Eragrostietalia \& Cl. Stellarietea mediae

Amaranthus retroflexus

Cirsium incanum

Chenopodium album

Cyperus rotundus

Veronica persica

Polygonum aviculare

Sinapis arvensis

Anthemis altissima

Hibiscus trionum

Setaria pumila

Convolvulus arvensis

Setaria viridis

Echinochloa crus-galli

Sporadic species: Amaranthus blitum 5; Amaranthus lividus 3; Anagallis foemina 4; Chenopodium botrys 4; Cynodon dactylon 5(1); Malva neglecta 5(1); Solanum nigrum 3; Sorghum halepense 1; Xanthium italicum 3.

Others

\begin{tabular}{llllllll} 
Medicago lupulina & + & + & + & + &. & 4 \\
Melilotus indicus & + & + & + & + &. & 4 \\
Rumex halacsyi & + & + & + &. &. & 3 \\
Sporadic species: Plantago major 5. & & & & & & & \\
\hline
\end{tabular}

Locality of relevé: 1 - (383447,8; 684232,3); 2 - (383447,8; 684232,3); 3 - $(383447,8 ; 684232,3) ; 4$ - $(383447,8 ; 684232,3) ; 5$ - (395659,8; $690005,1)$.

383310,2; 683410,5; date: 2011.05.30; altitude: $848 \mathrm{~m}$; cover of herb layer: $35 \%$; relevé area: $30 \mathrm{~m}^{2}$; $\mathrm{pH}$ : 7.4; number of weeds: 15; cultivated plant: Solanum tuberosum 4; diagnostic species: Ass. Convolvulo arvensis-Cyperetum rotundi-Cyperus rotundus 1; SubAss. Convolvulo arvensis-Cyperetum rotundi kochietosum scopariae - Kochia scoparia 2; O. Atriplici-Chenopodietalia albi $\&$ Cl. Stellarietea mediae - Convolvulus arvensis 1 , Portulaca oleracea 1, Chenopodium album +, Amaranthus retroflexus +,
Cynodon dactylon 1, Polygonum aviculare +, Sinapis arvensis + , Veronica persica +, Galinsoga ciliata +; others - Plantago major + , Lolium perenne + , Rorippa palustris + , Helianthus tuberosus + ). Kochia scoparia in Tajikistan occurs in segetal as well as ruderal habitats; however, it creates frequent and constant compositions in segetal root-crop communities on sandy soils and fields close to road or railway verges, cities or villages.

\section{DATURO STRAMONII-HIBISCETUM TRIONI Bagrikova} (1996) 1997 (Tab. S2, rel. 1-12).

Diagnostic species: Hibiscus trionum, Datura stramonium.

Plots of this association have been observed spread mainly over the southern Tajikistan and Prisyrdaryan geobotanical regions. They are typified by loose cultivation of maize, cotton, lentils, onions, beans and, sporadically, carrots. The phytocoenoses were recorded within a range of altitudes from ca. 700 to 1000 meters above sea level (Fig. 4). The community prefers warm, deep, brown soils with inconsiderable gravel or sand content. The reaction of the substrate was neutral or slightly alkaline [ $\mathrm{pH} 7.0-7.3$ (7.7)]. Fields are often irrigated. In a single plot, between 10 and 20 species were noted. The average number of species per relevé was 14 . The maximum cover of weed species in the phytocoenoses was about $65 \%$, or, in most cases, ca. $45 \%$. Besides diagnostic species, this association is characterized by a high share of meadow or pasture species including Cynodon dactylon, Plantago major, and Polygonum persicaria. This is mainly because of the irrigation of the plantations. To the most constant taxa belong Amaranthus retroflexus, Abutilon theophrasti, Convolvulus arvensis, Solanum nigrum, Portulaca oleracea and Xanthium italicum. The diagnostic taxa generally prefer warm sites throughout the area of their occurrence in the east Mediterranean-Irano-Turanian region within medium-height mountainous locations.

SETARIO PUMILAE-SORGHETUM HALEPENSI Ştefan et Oprea 1997 (Tab. S2, rel. 13-20).

Diagnostic species: Sorghum halepense, Setaria pumila.

The association occurs sporadically in the southern Tajikistan geobotanical region. It prefers medium elevations, that is, altitudes of 800 to 1000 meters above sea level (Fig. 4). The association develops mainly in potato and lentil cultivations. Its phytocoenoses are associated with fertile, relatively dry, neutral or slightly alkaline soils, often with high sand content and quite loose. Between 10 and 20 species were recorded in a single plot (mean approx. 15). The phytocoenoses of Setario pumilae-Sorghetum halepensi association are characterized by a relatively high cover of herb layer. The maximum cover of weed species in the phytocoenoses was about $85 \%$. The mean cover of the whole "c" layer was ca. $65-70 \%$ (Fig. 4). The diagnostic Sorghum halepense has relatively high cover in all plots. To the most abundant and constant species found in phytocoenoses belong Xanthium italicum, Helianthus tuberosus, Echinochloa crus-galli and Cyperus rotundus. Cereal crop species from the Turgenio-Roemerietalia refractae order such as Avena trichophylla or Cirsium incanum were also noted in observed plots.

EQUISETO ARVENSI-XANTHIETUM ITALICI Kolev 1976 (Tab. S2, rel. 21-33).

Diagnostic species: Xanthium italicum.

The association is very distinct from other segetal weed communities noted in Tajikistan (Fig. 3). It is associated mainly with maize, lentil, potato, sunflower, and tomato fields situated at medium elevations within an altitudinal range of 

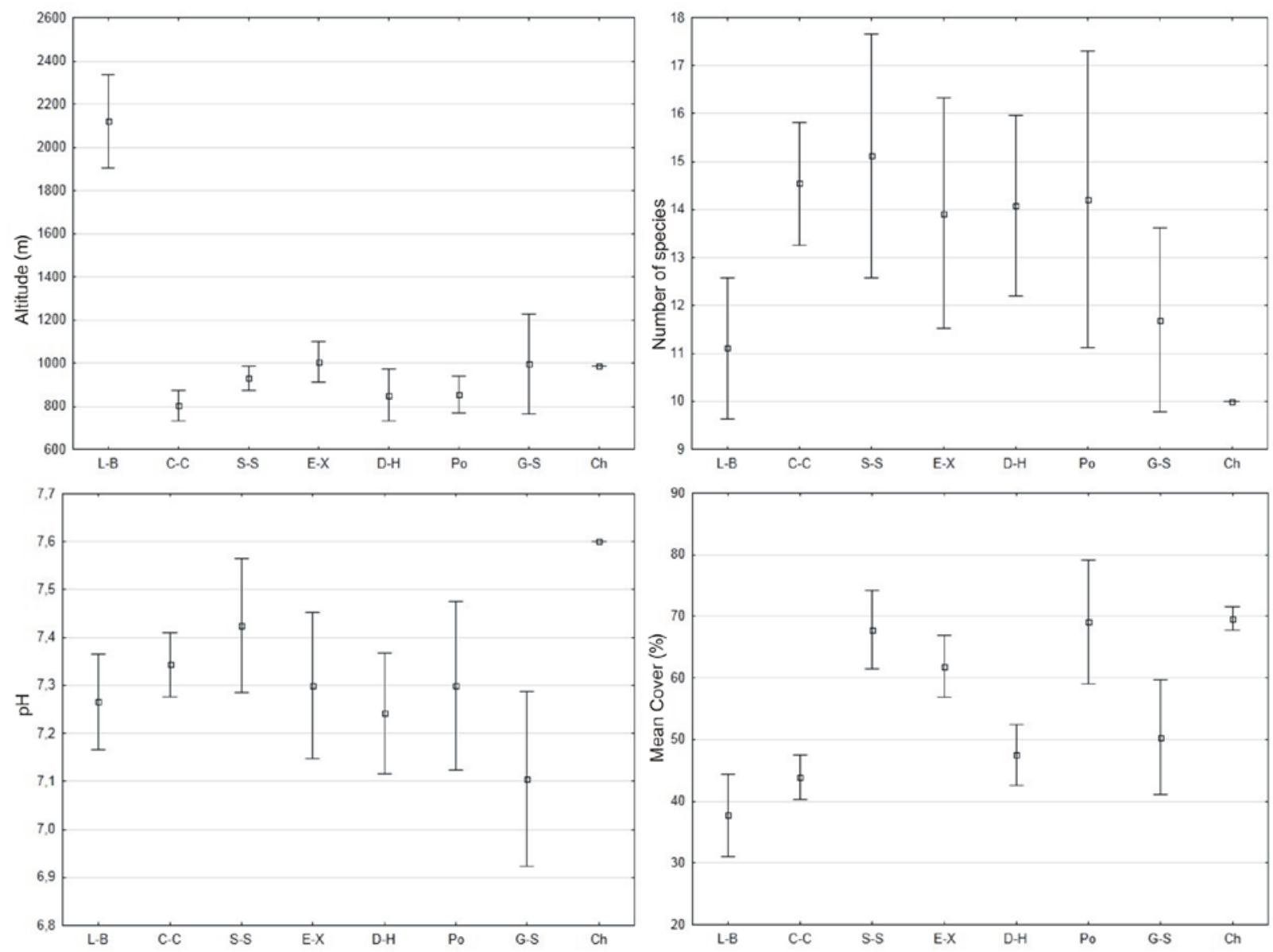

Fig. 4 Altitudinal distribution, richness, $\mathrm{pH}$ and mean cover of weeds in researched vegetation plots of Brassico campestris-Lamietum amplexicauli (L-B), Convolvulo arvensis-Cyperetum rotundi (C-C), Setario pumilae-Sorghetum halepensi (S-S), Equiseto arvensi-Xanthietum italici (E-X), Daturo stramonii-Hibiscetum trioni (D-H), Galinsogo-Setarietum (G-S), Portulacetum oleracei (Po) and community with Chrysanthemum coronarium (Ch).

800 to 1180 meters above sea level (Fig. 4). The association develops on relatively dry, sandy soil, or soil with significant stone content or gravel fraction substrates. The soil is neutral or slightly alkaline [pH 7.0-7.5(7.8)], moderately fertile, and sporadically irrigated. Plots of the association are moderately rich in species, containing from 10-24 taxa (mean approx. 14). The total cover of weed species in the phytocoenoses rarely exceeds $80 \%$, and in most cases it fluctuates around 60\% (Fig. 4). Typical for the observed plots was the relatively significant cover of the diagnostic species Xanthium italicum, which attains an average value of approx. 30-35\%. Among the species with the highest constancy are Setaria viridis, Galium spurium, Echinochloa crus-galli, Cichorium intybus, Chenopodium album and Convolvulus arvensis. In several plots, due to the irrigation, considerable cover of Cynodon dactylon was found. Also, the Cuscuta campestris which parasitise Xanthium italicum have significant cover in few plots.

\section{COMMUNITY WITH CHRYSANTHEMUM CORO-} NARIUM (Tab. S2, rel. 34-35).

Diagnostic species: Chrysanthemum coronarium.

The community with Chrysanthemum coronarium is extremely rare in Tajikistan. Plots of this community were found only in one location in the Vakhsh river valley at the altitude of ca. 1000 meters above sea level (Fig. 4). It has been noted in Lens culinaris and Solanum tuberosum plantations on deep, brown, loessic and slightly alkaline soil. The substrate was generally dry; however, it is supposed that the field undergoes irregular irrigation. Only 10 species were recorded in the relevés; thus, the association is among the poorest (Fig. 4). The diagnostic taxon has been observed in both plots, with considerable cover of $55-60 \%$. The total cover of weed species in the phytocoenoses does not exceed $65 \%$. The association is characterized by a high proportion of Stellarietea mediae species, e.g. Setaria viridis, Chenopodium album, Amaranthus retroflexus, Sorghum halepense or Cyperus rotundus (Tab. S2, rel. 34-35). Also, taxa typical for cereal crop vegetation from the Turgenio-Roemerietalia refractae order were noted in phytocoenoses (e.g. Anthemis altissima, Avena trichophylla). This is related to the crop rotation cycle and the proximity of cereal and root crops.

GALINSOGO-SETARIETUM (R. Tx. et Beck. 1942) R. Tx. 1950 (Tab. 1, rel. 1-7).

Diagnostic species: Galinsoga parviflora, Galinsoga ciliata.

The association was found in only a few places in Tajikistan, in sandy fields, mainly around Dushanbe in the southern Tajikistan region. Plots of the phytocoenosis were noted at altitudes of ca. 1000-1200 meters above sea level (mean approx. 1180; Fig. 4). The association was found mostly in potato cultivations. Its phytocoenoses are associated with moderately fertile, mesic dry and neutral ( $\mathrm{pH}$ 6.8-7.2) brown soils, which contain a high percentage of sand or gravel fractions. The researched plots were species-poor, containing on average approx. 13 species 
in a single patch. The phytocoenoses of Galinsogo-Setarietum are characterized by a relatively high cover of herb layer due to the considerable domination of Galinsoga parviflora, Kochia scoparia or Oxalis fontana. Apart from diagnostic species, plots of this association often include Sonchus oleraceus, Plantago lanceolata, Polygonum persicaria, Trifolium repens and Polygonum aviculare (Tab. 1).

\section{BRASSICO CAMPESTRIS-LAMIETUM AMPLEXICAULI} ASS. NOVA (Tab. 2, rel. 1-18).

Typus relevé: Tab. 2, rel. 14.

Diagnostic species: Lamium amplexicaule, Brassica campestris.

The association is the least thermophilous syntaxon of all those recorded in root crops in Tajikistan. It occurs mostly in the Zeravshanian, Hissar-Darvasian and eastern Tajikistanian geobotanical regions at relatively high altitudes, from generally 1900 to 2500 meters above sea level (mean approx. 2100; Fig. 4). The association develops mainly in potato cultivations. Its phytocoenoses are associated with unfertile, neutral or moderately alkaline, grey soils and rankers, which are often very stony and loose. Recorded plots were sometimes observed on northern slopes of alpine river valleys (e.g. Yagnob, Pastrud Darya, Iskander Darya) or on northern rock walls. Between 5 and 17 weeds were recorded in a single plot (mean approx. 11). The plots of the Brassico campestris-Lamietum amplexicauli association are characterized by a relatively low cover of herb layer. The maximum cover of weed species in the phytocoenoses was about $70 \%$. The mean cover of the whole "c" layer was ca. 35\% (Fig. 4). Co-occurring species generally represent root-crop weeds (e.g. Chenopodium album, Sonchus oleraceus). However, there is also a relatively considerable share of cereal-crop field species (e.g. Fagopyrum tataricum, Lepyrodiclis holosteoides, Torilis leptophylla). These phytocoenoses are also supported by species typical for ruderal habitats, like Sisymbrium altissimum or Melilotus officinalis (Tab. 2).

PORTULACETUM OLERACEI Felföldy 1942 (Tab. 3, rel. 1-5). Syn.: Digitario-Portulacetum (Felföldy 1942) Timár et Bodrogk. (1953) 1955; Convolvulo-Portulacetum Ubrizsy 1949, 1950).

Diagnostic species: Portulaca oleracea.

The association of Portulacetum oleracei is among the most widely distributed in Tajikistan. However, within vegetable crops it was found sporadically. Phytocoenoses dominated by Portulaca oleracea developed mostly at middle elevations of river valleys in the southern Tajikistanian and Prisyrdaryan geobotanical regions, mostly at altitudes of ca. 750-950 meters above sea level. Portulacetum oleracei occurs mainly in potato plantations. The association develops on moist and fertile, deep, brown soils with a relatively high content of sand or gravel. The substratum is close to neutral ( $\mathrm{pH}$ approx. 7.2-7.5; Fig. 4). Fields are located in sunny places and sometimes irrigated. Portulaca oleracea is always apparently dominant. The cover of this diagnostic species exceeds $60 \%$. The phytocoenoses of the association feature significant total cover of weeds, more than $70 \%$. In phytocoenoses relatively rich in species, ca. 14 taxa have been noted on average. Co-occurring species represent segetal (e.g. Echinochloa crus-galli, Chenopodium album, Setaria viridis, Amaranthus retroflexus, Veronica persica) or ruderal (e.g. Melilotus indicus, Malva neglecta, Amaranthus blitum, Cynodon dactylon) vegetation (Tab. 3 ).

\section{Synopsis of syntaxa}

Based on this study, we propose the following classification of the weed communities of root crops in Tajikistan:

Stellarietea mediae Tüxen et al. ex von Rochow 1951 Atriplici-Chenopodietalia albi R.Tüxen (1937) Nordhagen 1940

Spergulo arvensis-Erodion cicutariae J. Tüxen in Passarge 1964

[Syn. Panico-Setarion Sissingh in Westhoff, Dijk et Passchier 1946 - \$2b, nomen nudum; Digitario-Setarion (Sissingh in Westhoff et al. 1946) Hüppe et Hofmeister 1990]

1. Convolvulo arvensis-Cyperetum rotundi Carretero et Aguilella ex Ninot, X. Font, Masalles et Vigo 2010-2011

- Convolvulo arvensis-Cyperetum rotundi kochietosum scopariae S. Nowak \& A. Nowak subass. nova

2. Daturo stramonii-Hibiscetum trioni Bagrikova (1996) 1997

3. Setario pumilae-Sorghetum halepensi Ştefan et Oprea 1997

4. Equiseto arvensi-Xanthietum italici Kolev 1976

5. Comm. with Chrysanthemum coronarium Oxalidion fontanae Passarge 1978

(Syn. Spergulo-Oxalidion Görs in Oberdorfer et al. 1967 - \$2b, nomen nudum; Polygono-Chenopodion polyspermi sensu auct. non Koch 1926 - pseudonym)

6. Galinsogo-Setarietum (R. Tx. et Beck. 1942) R.

Tx. 1950

Veronico-Euphorbion Sissingh ex Passarge 1964

(Syn. Veronico-Euphorbion Sissingh 1942 - ms. \$1; Fumario-Euphorbion Müller ex Görs 1966)

7. Brassico campestris-Lamietum amplexicauli S.

Nowak \& A. Nowak ass. nova

Eragrostietalia J. Tüxen ex Poli 1966

Eragrostion cilianensi-minoris Tüxen ex Oberdorfer 1954

(Syn. Amarantho-Chenopodion albi Morariu 1943 $\$ 3 \mathrm{~b}$; Eragrostenion Tüxen 1950 - $\$ 2$ b, nomen nudum, suballiance; Panico-Setarion Sissingh ex von Rochow 1951 - \$36, nomen ambiguum; Tribulo-Eragrostion poaeodis Soó et Tímár in Tímár 1957; Eragrostio-Polygonion arenastri Couderc et Izco ex Čarni et Mucina 1998; Euphorbion prostratae sensu Mucina in Mucina et al. 1993 non Rivaz-Martínez 1976 - pseudonym)

8. Portulacetum oleracei Felföldy 1942

\section{Discussion}

So far, few studies concerning segetal weeds in Tajikistan have been published, and the existing publications were issued quite a long time ago (e.g. [100]). To discover distribution patterns and the species richness of Tajikistan's segetal flora, a reconnaissance field study and a research query were conducted in the years 2008-2010. As a result of the analyses, it was determined that Tajikistan's segetal flora consists of 689 taxa. The most weed-abundant families include Fabaceae, Asteraceae, Chenopodiaceae, Lamiaceae, Boraginaceae and Brassicaceae. The most weed-rich regions of the country are the southwestern areas, i.e. the southern Tajikistanian geobotanical region where over 500 species were observed. Also, the Hissar-Darvasian, 
Prisyrdaryan and Zeravshanian regions, where approx. 350 weed species occur, are also rich in segetal flora. As regards vertical distribution, the largest weed species richness was observed within the range of 800 to 1700 meters above sea level. Due to very extensive agriculture as well as relatively small fields, weed occurrence is frequent outside segetal communities in Tajikistan. Weeds were usually noted in riverbed gravels, screes, wastelands, rushes, xerothermic grasslands and in typical ruderal communities [101]. The richness of the segetal communities is clearly visible when the number of species in separate patches of vegetation, with up to 50 taxa per plot in crop cultivations, is considered. The total number of species detected in the data set as a whole is significant. This is relatively rich flora when compared to other crop cultivation areas in the world (e.g. [35,36,39,50,71,102]).

The floristic structure and separateness of the community makes it necessary to distinguish a new association: Brassico campestris-Lamietum aplexicauli. This is one of the most interesting phytocoenoses occurring in the highest elevations occupied by root-crop cultivations in the Pamir Alai Mts (ca. 1900-3000 meters above sea level). The association corresponds with another typically mountainous segetal community known from cereal-crop fields of the Middle Asia: Fagopyro tatariciLathyretum sativi [83]. Both associations have developed on similar soils and have many species in common, such as: Brassica campestris, Fagopyrum tataricum, Lepyrodiclis holosteoides or Torilis leptophylla. However, the cereal association has a clearly narrower range, being restricted to the eastern Pamir.

Another interesting root-crop association is Convolvulo arvensis-Cyperetum rotundi Carretero et Aguilella ex Ninot, X. Font, Masalles et Vigo 2010-2011. This phytocoenosis is apparently related to irrigated fields and has the greatest share in cotton plantations. The association was described as a weed community chiefly formed by geophytes like Cyperus rotundus and Convolvulus arvensis and including other generalist ruderals like Portulaca oleracea, Amaranthus blitum or A. retroflexus [97]. Although it has been suggested that the community develops under a cultivation regime of low intensity, including irrigation, it seems obvious that compared to a more continental climate (e.g. littoral Mediterranean conditions in Spain), in Tajikistan the association needs quite intensive irrigation. It is one of the most widespread segetal plant associations in Tajikistan. Because of the abundant occurrence of Cyperus rotundus it could be compared to Setario ambiguae-Cyperetum rotundi Brullo, Scelsi \& Spampinato 2001 from Sicily, which also occurs in alluvial, moist soils within the thermo- and mesomediterranean bioclimatic belts, but generally in citrus groves [45]. It could be also compared to Digitario sanguinalis-Cyperetum rotundi Bergmeier 2008, known from sandy or loamy-sandy alkaline soils from citrus cultivations in Crete [103].

As Convolvulo arvensis-Cyperetum rotundi has frequently been found in Europe in ruderal habitats or fields and orchards close to disturbed biotopes, a subassociation characterized by a considerably high share of Kochia scoparia could be distinguished. In researched plots in Tajikistan several relevés are dominated by Kochia scoparia; thus it seems plausible to separate the new syntaxon at the lowest rank as a segetal phytocoenosis closely related to communities from the Atriplicion alliance (e.g. $[95,97,104-106])$.

Another thermophilous association typical for arable root crop cultivations is Daturo stramonii-Hibiscetum trioni Bagrikova (1996) 1997. It has been recently described from vineyards of Crimea [96] as a species-poor community from the Atriplici-Chenopodietalia albi order. Considering the floristic structure, habitat conditions and climatic circumstances, the plots from Tajikistan are truly comparable to those reported from Crimea. The difference is in cultivated plants, as in Tajikistan the Daturo stramonii-Hibiscetum trioni association was found mainly in plantations of maize, cotton, lentils, onions, and beans, but not of potatoes. Also, the share of Cynodon dactylon is higher here, making the plots similar to Hibisco trioni-Cynodontetum Kolev 1976 described from the Balkans [50]. However, this species has broader ecological amplitude in the Middle Asia, is not typical for segetal vegetation and its presence and abundance depends mainly on irrigation and trampling by cattle after harvest of the cultivation crop. Therefore, Cynodon dactylon seems not to be an appropriate diagnostic species for the association or alliance. This species, as well as other $\mathrm{C} 4$ grasses, have been reported as diagnostic for the ruderal and sometimes also segetal syntaxa from the Eragrostion cilianensi-minoris alliance typical for warm synanthropic habitats with sandy or gravelly soils. The studies of Čarni \& Mucina [107], Kropač [108], Borhidi [109], Sanda et al. [47], Lososova et al. [36] and Němec et al. [110] have revealed the Hibisco trioni-Eragrostietum poaeoidis Soó et Tímár 1957 to be a rare association inhabiting arable fields mainly containing root crops, trampled habitats and recently disturbed synanthropic sites in Central Europe and the Balkans. However, due to a colder and wetter climate, the syntaxon has a higher level of participation of Eurosiberian or Boreal species in comparison to plots found in Tajikistan, where Irano-Turanian and Mediterranean taxa clearly prevail.

Several relevés have been identified as Portulacetum oleracei Felföldy 1942. This is a commonly occurring association throughout the eastern Mediterranean and Irano-Turanian provinces, known from vineyards, lavender, root crops and cotton plantations as well as orchards and vegetable gardens $[47,94,96,109,111]$. In Tajikistan it develops mainly in poorly managed vegetable gardens with the lowest cultivation intensity. In these plots the crop cover is relatively low; thus the total weed cover can attain high values. The Portulacetum oleracei association has a rather insignificant share of ruderal species, such as Malva neglecta, Amaranthus lividus, or A. blitum. The association is confined to sunny places, close to ruderal habitats, with sandy substrata, often well supplied with water (irrigation) and nitrates.

Equiseto arvensi-Xanthietum italici Kolev 1976 develops on moderately fertile, often sandy or gravelly soils. The association was described from sandy fields in Bulgaria [50]. Despite the absence of Equisetum arvense, which has a different ecological amplitude in Tajikistan (occurring mainly in bogs and riverside forests), plots with abundant occurrence of Xanthium italicum have been identified as Equiseto-Xanthietum italici because of floristic and habitat similarities to phytocoenoses known from the Balkans. The association shows a relative preference for the driest locations; however, it has also been observed in plots under an irrigation regime. Xanthium italicum prefers such unstable and changing moisture conditions. The species is regarded as diagnostic to associations typical for inundated river alluvials such as Xanthio strumarii-Bidentetum Timár 1947 from the Bidentetea class [47].

Another association occurring on relatively dry substrates is Setario pumilae-Sorghetum halepensi Ştefan et Oprea 1997. It is known from Romania and adjacent areas where it grows in irrigated fields, mainly root crops. In Tajikistan the association develops sporadically in the southern Tajikistanian geobotanical 
region. As in Europe, it is a rather species-poor association apparently dominated by grass species such as diagnostic Sorghum halepense or Setaria pumila. There is still a need to explore the communities of Sorgum halepense in more detailed studies and find its relation to other associations, such as Chondrillo junceae-Sorghetum halepensis Kolev 1976 (described from cereals in the Balkans [50]) or Hibisco trioni-Sorghetum halepensi (described from Dalmatia [112]). Also, Galinsogo-Setarietum merits further research in Tajikistan focusing especially on the syntaxonomical position of this community. Temporarily, it was classified to the Oxalidion fontanae alliance Passarge 1978 (Polygono-Chenopodion polyspermi sensu auct. non Koch 1926 - pseudonym) because of its considerable share of Oxalis fontana, Sonchus oleraceus and Veronica persica. However the significant participation of Setaria pumila and S. viridis renders the association similar to Setario pumilae-Echinochloëtum cruris-galli Felföldy 1942 corr. Mucina in Mucina et al. 1993 (syn. Setario glaucae-Galinsogetum parviflorae Tüxen 1950) classified in Spergulo arvensis-Erodion cicutariae J. Tüxen in Passarge 1964 (syn. Panico-Setarion).

Other root-crop associations play a minor role in segetal habitats of Tajikistan; however, they significantly contribute to the diversity of agrocoenoses. There is still a need for further research in root-crop communities of Tajikistan and the Middle Asia. Some of the above-mentioned syntaxa (e.g. BrassicoLamietum or Convolvulo-Cyperetum) are significantly diversified in terms of floristic structure; hence, after collection of more data or enlargement of the survey area, it would seem possible to describe new syntaxa with at least subassociation rank. Taking more relevés may help to classify the community of Chrysanthemum coronarium and to discover its relation to Asphodelo fistulosi-Hordeetum leporini O. Bolòs 1956 chrysanthemetosum coronarii, Resedo albae-Chrysanthemetum coronarii $\mathrm{O}$. Bolòs et Molinier 1958 or Malvo parviflorae-Chrysanthemetum coronarii Ferro 1980 [113-115]. Chorological analyses and conservation considerations will also be of great importance in discovering the present distribution patterns of weed flora of Tajikistan.

\section{Acknowledgments}

The authors wish to thank F. Abdurahimova from the Nature Protection Team Dushanbe for assistance in organizing expeditions. We also are very grateful to G. Lazkov for his help in species determination. The project was partially funded by the Polish Ministry of Science, grant No. N304 377838/ 2010.

\section{Authors' contributions}

The following declarations about authors' contributions to the research have been made: field research, idea and manuscript preparation: SN; field research: ASN.

\section{Supplementary material}

The following supplementary material for this article is available online at http://pbsociety.org.pl/journals/index.php/ asbp/rt/suppFiles/1365/ 0:

1. Tab. S1 Convolvulo arvensis-Cyperetum rotundi.

2. Tab. S2 Associations and communities of the Spergulo arvensis-Erodion cicutariae alliance.

\section{References}

1. Ovchinnikov PN, editor. Flora Tadzhikskoi SSR. Vol. I, Paprotnikoobraznye - Zlaki. Moscow: Izdatelstvo Akademii Nauk SSSR; 1957.

2. Ovchinnikov PN, editor. Flora Tadzhikskoi SSR. Vol. II, Osokovye - Orkhidnye. Moscow: Izdatelstvo Akademii Nauk SSSR; 1963.

3. Ovchinnikov PN, editor. Flora Tadzhikskoi SSR. Vol. III, Orekhovye Gvozdichnye. Leningrad: Izdatelstvo Nauka; 1968.

4. Ovchinnikov PN, editor. Flora Tadzhikskoi SSR. Vol. V, Krestotsvetne Bobovye. Leningrad: Izdatelstvo Nauka; 1978.

5. Ovchinnikov PN, Kochkareva TF, editors. Flora Tadzhikskoi SSR. Vol. IV, Rogolistnikovye - Rozotsvetnye. Leningrad: Izdatelstvo Nauka; 1975.

6. Ovchinnikov PN, Kinzikaeva GK, editors. Flora Tadzhikskoi SSR. Vol. VI, Bobovye (rod Astragal) - Tsinomorievye. Leningrad: Izdatelstvo Nauka; 1981.

7. Kinzikaeva GK, editor. Flora Tadzhikskoi SSR. Vol. IX, Marenovye - Slozhnotsvetnye. Leningrad: Izdatelstvo Nauka; 1988.

8. Rasulova MR, editor. Flora Tadzhikskoi SSR. Vol. X, Slozhnotsvetnye. Leningrad: Izdatelstvo Nauka; 1991.

9. Zakirov KZ. Flora i rastitelnost basseina reki Zeravshan. 2, konspekt flory. Tashkent: Akademia Nauk Uzbekskoi SSR; 1961. (vol 2).

10. Tzvelev NN. Zlaki SSSR. Leningrad: Izdatelstvo Nauka; 1976.

11. Ikonnikov SS. Notulae ad floram Pamir and Badachschan. Novisti Sist Vyssh Rast. 1983;20:187-195.

12. Lazkov G. Gastrolychnis alexeenkoi Lazkov (Caryophyllaceae) - a new species to the flora of Tajikistan. Novisti Sist Vyssh Rast. 2008;40:68-69.

13. Nobis M, Nowak A, Zalewska-Gałosz J. Potamogeton pusillus agg. in Tajikistan (Middle Asia). Acta Soc Bot Pol. 2010;79(3):235-238.

14. Nobis M, Kowalczyk T, Nowak A. Eleusine indica (Poaceae): a new alien species in the flora of Tajikistan. Pol. Bot J. 2011;56(1):121-123.

15. Nobis M. Remarks on the taxonomy and nomenclature of the Stipa tianschanica complex (Poaceae), on the base of a new record for the flora of Tajikistan (central Asia). Nord J Bot. 2011;29:194-199. http://dx.doi. org/10.1111/j.1756-1051.2010.00869.x

16. Nobis M, Nowak A. New data on the vascular flora of the central Pamir Alai Mountains (Tajikistan, Central Asia). Pol Bot J. 2011;56(2):195-201.

17. Nobis M, Nowak A. New data on the vascular flora of the central Pamir Alai Mountains (Tajikistan, Central Asia). Part II. Cas Slez Muz Opava. 2011;60:259-262. http://dx.doi.org/10.2478/v10210-011-0029-0

18. Fritsch RM, Khassanov FO, Matin F. New Allium taxa from Middle Asia and Iran. Stapfia. 2002;80:381-393.

19. Khassanov FO, Shomuradov H, Tobaev K. A new Allium L. species from Middle Asia. Linz. Biol Beitr. 2007;39(2):799-802.

20. Fritsch RM, Friesen N. Allium oreotadzhikoru and Allium vallivanchense, two new species of Allium subg. Polyprason (Alliaceae) from the Central Asian republic Tajikistan. Feddes Repert. 2009;120(3-4):221-231. http:// dx.doi.org/10.1002/fedr.200911199

21. Ranjbar M, Karamian R, Vitek E. Onobrychis dushanbensis sp. nova endemic to Tajikistan. Nord J Bot. 2010;28:182-185. http://dx.doi. org/10.1111/j.1756-1051.2009.00628.x

22. Nobis M. Stipa $\times$ brozhiana (Poaceae) nothosp. nov. from the western Pamir Alai Mts (middle Asia) and taxonomical notes on Stipa $\times$ tzvelevii. Nord J Bot. 2011;29:458-464. http://dx.doi.org/10.1111/j.1756-1051.2011.01127.x

23. Nobis M, Nowak A, Nobis A. Stipa zeravshanica (Poaceae) a new endemic species from rocky walls of the western Pamir Alai Mountains (Tajikistan, middle Asia): taxonomy, distribution and habitat ecology. Nord J Bot. In press. http://dx.doi.org/10.1111/j.1765-1051.2013.00184.x

24. Nobis M. Stipa narynica sp. nov. (Poaceae) from the western TianShan Mountains. Nord J Bot. 2012;30(1):70-76. http://dx.doi. org/10.1111/j.1756-1051.2011.01403.x

25. Nobis M. Taxonomic revision of the Stipa lipskyi group (Poaceae: Stipa section Smirnovia) in the Pamir Alai and Tian-Shan Mountains. Plant Syst Evol. In press. http://dx.doi.org/10.1007/s00606-013-0799-5 
26. Vavilov NI. The origin, variation, immunity and breeding of cultivated plants: selected writings. New York NY: Ronald Press Co.; 1951. (Chronica Botanica; vol 13).

27. Nowak A, Nobis M. Tentative list of endemic vascular plants of Zeravshan Mts in Tajikistan (Middle Asia): distribution, habitat preferences and conservation status of species. Biodiv Res Conserv. 2010;19:65-80. http:// dx.doi.org/10.2478/v10119-010-0011-5

28. Nowak A, Nowak S, Nobis M. Distribution patterns, ecological characteristic and conservation status of endemic plants of Tadzhikistan - a global hotspot of diversity. J Nat Conserv. 2011;19(5):296-305. http://dx.doi.org/10.1016/j. jnc.2011.05.003

29. Mittermeier R, Gil PR, Hoffman M, Pilgrim J, Brooks T, Goettsch-Mittermeier C, et al. Hotspots revisited: Earth's biologically richest and most endangered terrestrial ecoregions. Arlington VA: Conservation International; 2005.

30. Giam X, Bradshaw CJA, Tan HTW, Sodhi NS. Future habitat loss and the conservation of plant biodiversity. Biol Conserv. 2010;143(7):1594-1602. http://dx.doi.org/10.1016/j.biocon.2010.04.019

31. Fay M, Patel H. A simple index of vulnerability to climate change. Washington DC: World Bank; 2008. (Adapting to climate change in Europe and Central Asia).

32. Baettig MB, Wild M, Imboden DM. A climate change index: where climate change may be most prominent in the 21st century. Geophys Res Lett. 2007;34(1):457-469. http://dx.doi.org/10.1029/2006GL028159

33. Pott R. Die Pflanzengesellschaften Deutschlands. 2nd ed. Stuttgart: Eugen Ulmer Verlag; 1995.

34. Schubert R, Hilbig W, Klotz S. Bestimmungsbuch der Pflanzengesellschaften Mittel- und Nordostdeutschlands. Stuttgart: Springer Spektrum; 1995.

35. Lososová Z. Weed vegetation in southern Moravia (Czech Republic): a formalized phytosociological classification. Preslia. 2004;76:65-85.

36. Lososová Z, Chytrý M, Cimalová Š, Otýpková Z, Pyšek P, Tichý L. Classification of weed vegetation of arable land in the Czech Republic and Slovakia. Folia Geobot. 2006;41(3):259-273. http://dx.doi.org/10.1007/BF02904941

37. Matuszkiewicz W. Przewodnik do oznaczania zbiorowisk roślinnych Polski. Warsaw: Polish Scientific Publishers PWN; 2007.

38. Šilc U, Čarni A. Formalized classification of the weed vegetation of arable land in Slovenia. Preslia. 2007;79:283-302.

39. Kropáč Z, Mochnacký S. Contribution to the segetal communities of Slovakia. Thaiszia. 2009;19:145-211.

40. Sádlo J, Kolbek J. The terrestrial ruderal and segetal vegetation of North Korea: a synthesis. Folia Geobot. 1997;32(1):25-40. http://dx.doi. org/10.1007/BF02803882

41. Yamalov SM, Martynenko WB, Golub WB, Baisheva EZ. Prodromus rastitelnych soobshchestv respubliki Bashkortostan. Ufa: Akademia Nauk Rasii; 2004.

42. Yamalov SM, Shaikhislamova EF, Mirkin BM. The segetal vegetation of Bashkirian Transural. Rastit. Rasii. 2007;10:89-99.

43. Gilli A. Afghanische Ruderal - und Segetalgesellschaften. Feddes Repert. 1975;86(3):171-197. http://dx.doi.org/10.1002/fedr.19750860303

44. Bergemeier E. The diversity of segetal weeds in crete (greece) atspecies and community level. Ann Bot (Roma). 2006;6:53-64. http://dx.doi.org/10.4462/ annbotrm-9160

45. Brullo S, Giusso Del Galdo G, Guarino R, Minissale P. A survey of the weedy communities of Sicily. Ann Bot (Roma). 2007;7:127-161. http:// dx.doi.org/10.4462/annbotrm-9091

46. Zamora J, Verdu J, Galante E. Species richness in Mediterranean agroecosystems: spatial and temporal analysis for biodiversity conservation. Biol Conserv. 2007;134(1):113-121. http://dx.doi.org/10.1016/j.biocon.2006.08.011

47. Sanda V, Öllerer K, Burescu P. Fitocenozele din România: sintaxonomie, structură, dinamică şi evoluție. Bucharest: Ars Docendi - Universitatea din Bucuresti; 2008.

48. Vrbnicanin S, Stevanovic Z, Radovanov K, Uludağ A. Weed vegetation of small grain crops in Serbia: environmental and human impacts. Turk J Agric For. 2009;33:325-337.
49. Šilc U, Vrbnicanin S, Božić D, Čarni A, Stevanovic ZD. Weed vegetation in the north-western Balkans: diversity and species composition. Weed Res. 2009;49(6):602-612. http://dx.doi.org/10.1111/j.1365-3180.2009.00726.x

50. Tzonev RT, Dimitrov MA, Heywood VH. Syntaxa according to the BraunBlanquet approach in Bulgaria. Phytol Balc. 2009;15(2):209-233.

51. Tamado T, Milberg P. Weed flora in arable fields of eastern Ethiopia with emphasis on the occurrence of Parthenium hysterophorus. Weed Res. 2000;40(6):507-521. http://dx.doi.org/10.1046/j.1365-3180.2000.00208.x

52. Karar RO, Mohamed BF, Marrs RH. Factors influencing the weed flora in the Gezira Scheme, Sudan. Weed Res. 2005;45(2):121-129. http://dx.doi. org/10.1111/j.1365-3180.2004.00441.x

53. Wittig R, Becker U, Ataholo M. Weed communities of arable fields in the Sudanian and the Sahelian zone of West Africa. Phytocoenologia. 2011;41(2):107-164. http://dx.doi.org/10.1127/0340-269X/2011/0041-0457

54. Hyvönen T, Salonen J. Weed species diversity and community composition in cropping practices at two intensity levels - a six-year experiment. Plant Ecol. 2002;159(1):73-81. http://dx.doi.org/10.1023/A:1015580722191

55. Robinson RA, Sutherland WJ. Post-war changes in arable farming and biodiversity in Great Britain. J Appl Ecol. 2002;39(1):157-176. http://dx.doi. org/10.1046/j.1365-2664.2002.00695.x

56. Gerowitt B, Bertke E, Hespelt SK, Tute C. Towards multifunctional agriculture - weeds as ecological goods? Weed Res. 2003;43(4):227-235. http:// dx.doi.org/10.1046/j.1365-3180.2003.00340.x

57. Storkey J. A functional group approach to the management of UK arable weeds to support biological diversity. Weed Res. 2006;46(6):513-522. http:// dx.doi.org/10.1111/j.1365-3180.2006.00528.x

58. Türe C, Böcük H. Investigation of threatened arable weeds and their conservation status in Turkey. Weed Res. 2008;48(3):289-296. http://dx.doi. org/10.1111/j.1365-3180.2008.00630.x

59. Lososová Z, Cimalová Š. Effects of different cultivation types on native and alien weed species richness and diversity in Moravia (Czech Republic). Basic Appl Ecol. 2009;10(5):456-465. http://dx.doi.org/10.1016/j.baae.2008.11.001

60. Pinke G, Pál R, Botta-Dukát Z, Chytrý M. Weed vegetation and its conservation value in three management systems of Hungarian winter cereals on base-rich soils. Weed Res. 2009;49(5):544-551. http://dx.doi. org/10.1111/j.1365-3180.2009.00730.x

61. Lososová Z, Chytrý M, Cimalová S, Kropáč Z, Otýpková Z, Pyšek P, et al. Weed vegetation of arable land in Central Europe: gradients of diversity and species composition. J Veg Sci. 2004;15(3):415-422. http://dx.doi. org/10.1111/j.1654-1103.2004.tb02279.x

62. Pyšek P, Jarošík V, Kropáč Z, Chytrý M, Wild J, Tichý L. Effects of abiotic factors on species richness and cover in Central European weed communities. Agric Ecosyst Env. 2005;109(1-2):1-8. http://dx.doi.org/10.1016/j. agee.2005.02.018

63. Fried G, Norton LR, Reboud X. Environmental and management factors determining weed species composition and diversity in France. Agric Ecosyst Env. 2008;128(1-2):68-76. http://dx.doi.org/10.1016/j.agee.2008.05.003

64. Lososová Z, Chytrý M, Kühn I. Plant attributes determining the regional abundance of weeds on central European arable land. J Biogeogr. 2008;35(1):177-187. http://dx.doi.org/10.1111/j.1365-2699.2007.01778.x

65. Cimalová $̌$, Lososová Z. Arable weed vegetation of the northeastern part of the Czech Republic: effects of environmental factors on species composition. Plant Ecol. 2008;203(1):45-57. http://dx.doi.org/10.1007/s11258-008-9503-1

66. Barrett SCH, Seaman DE. The weed flora of Californian rice fields. Aquat Bot. 1980;9:351-376. http://dx.doi.org/10.1016/0304-3770(80)90036-4

67. Camenisch M, Cook CDK. Wiesneria triandra (Dalzell) Micheli (Alismataceae): a rare and unusual south Indian endemic. Aquat Bot. 1996;55(2):115131. http://dx.doi.org/10.1016/S0304-3770(96)01065-0

68. Turki Z, Sheded M. Some observations on the weed flora of rice fields in the Nile Delta, Egypt. Feddes Repert. 2002;113(5-6):394-403. http://dx.doi. org/10.1002/1522-239X(200210)113:5/6<394::AID-FEDR394>3.0.CO;2-0

69. Freemark KE, Boutin C, Keddy CJ. Importance of farmland habitats for conservation of plant species. Conserv Biol. 2002;16(2):399-412. http:// 
dx.doi.org/10.1046/j.1523-1739.2002.00387.x

70. Bambaradeniya CNB, Edirisinghe JP, De Silva DN, Gunatilleke CVS, Ranawana KB, Wijekoon S. Biodiversity associated with an irrigated rice agro-ecosystem in Sri Lanka. Biodivers Conserv. 2004;13(9):1715-1753. http://dx.doi.org/10.1023/B:BIOC.0000029331.92656.de

71. Hilbig W. Schutz und Erhaltung der Segetalvegetation und ihrer gefährdeten Arten (Ackerwildpflanzenschutz). Feddes Repert. 2002;113(5-6):404-421. http://dx.doi.org/10.1002/1522-239X(200210)113:5/6<404::AIDFEDR404>3.0.CO;2-W

72. Warcholińska AU. Threatened segetal flora species of the Łódź Heights. Biodiv Res Conserv. 2006;3-4:391-394.

73. Anioł-Kwiatkowska J. Zagrożenia flory synantropijnej Dolnego Śląska problem wymierania archeofitów. In: Kącki Z, editor. Zagrożone gatunki Dolnego Śląska. Wrocław. Wrocław: University of Wrocław, PTPP Pro Natura; 2003. p. 151-164.

74. Storkey J, Westbury DB. Managing arable weeds for biodiversity. Pest Manag Sci. 2007;63(6):517-523. http://dx.doi.org/10.1002/ps.1375

75. Romero A, Chamorro L, Sans FX. Weed diversity in crop edges and inner fields of organic and conventional dryland winter cereal crops in NE Spain. Agric Ecosyst Env. 2008;124(1-2):97-104. http://dx.doi.org/10.1016/j. agee.2007.08.002

76. van Calster H, Vandenberghe R, Ruysen M, Verheyen K, Hermy M, Decocq G. Unexpectedly high 20th century floristic losses in a rural landscape in northern France. J Ecol. 2008;96(5):927-936. http://dx.doi. org/10.1111/j.1365-2745.2008.01412.x

77. Sutcliffe OL, Kay QON. Changes in the arable flora of central southern England since the 1960s. Biol Conserv. 2000;93(1):1-8. http://dx.doi. org/10.1016/S0006-3207(99)00119-6

78. Kohler F, Vandenberghe C, Imstepf R, Gillet F. Restoration of threatened arable weed communities in abandoned mountainous crop fields. Restor Ecol. 2011;19(101):62-69. http://dx.doi.org/10.1111/j.1526-100X.2009.00641.x

79. Gibson RH, Nelson IL, Hopkins GW, Hamlett BJ, Memmott J. Pollinator webs, plant communities and the conservation of rare plants: arable weeds as a case study. J Appl Ecol. 2006;43(2):246-257. http://dx.doi. org/10.1111/j.1365-2664.2006.01130.x

80. Melander B, Holst N, Grundy AC, Kempenaar C, Riemens MM, Verschwele A, et al. Weed occurrence on pavements in five North European towns. Weed Res. 2009;49(5):516-525. http://dx.doi.org/10.1111/j.1365-3180.2009.00713.x

81. Nowak A, Nobis M. Distribution patterns, floristic structure and habitat requirements of the alpine river plant community Stuckenietum amblyphyllae ass. nova (Potametea) in the Pamir Alai Mountains (Tajikistan). Acta Soc Bot Pol. 2012;81(2):101-108. http://dx.doi.org/10.5586/asbp.2012.018

82. Nowak A, Nobis M. Distribution, floristic structure and habitat requirements of the riparian forest community Populetum talassicae ass. nova in the Central Pamir-Alaj Mts (Tajikistan, Middle Asia). Acta Soc Bot Pol. 2013;82:47-55. http://dx.doi.org/10.5586/asbp.2012.041

83. Nowak S, Nowak A, Nobis M, Nobis A. Weed vegetation of cereal crops in Tajikistan (Pamir Alai Mts., Middle Asia). Phytocoenologia. In press. http:// dx.doi.org/10.1127/0340-269X/2013/0043-0557

84. Hilbig W, Bumžaa D. Die Ackerunkrautvegetation der Mongolischen Volksrepublik. Arch. Für Naturchutz Landschaftforschung. 1985;25:19-32.

85. Vladimirova WN. Tipy klimatov. In: Narzikulov IK, Stanjukovich KW, editors. Atlas Tajikskoi SSR. Dushanbe-Moskva: Akademia Nauk Tadzhikskoi SSR; 1968. p. 54-55.

86. Latipova WA. Kolichestvo osadkov. In: Narzikulov IK, Stanjukovich KW, editors. Atlas Tajikskoi SSR. Dushanbe-Moskva: Akademia Nauk Tadzhikskoi SSR; 1968. p. 54-55.

87. Narzikulov IK, Stanjukovich KW, editors. Atlas Tajikskoi SSR. DushanbeMoskva: Akademia Nauk Tadzhikskoi SSR; 1968.

88. Braun-Blanquet J. Pflanzensoziologie, Gründzüge der Vegetationskunde. 3rd ed. Wien: Springer; 1964.

89. Tichý L. JUICE, software for vegetation classification. J Veg Sci. 2002;13(3):451-453. http://dx.doi.org/10.1111/j.1654-1103.2002.tb02069.x
90. Hill MO. TWINSPAN: A FORTRAN program for arranging multivariate data in an ordered two-way table by classification of the individuals and attributes. New York NY: Cornell University; 1979.

91. ter Braak CJF, Šmilauer P. CANOCO reference manual and CanoDraw for Windows user's guide: software for Canonical Community Ordination (version 4.5). New York NY: Microcomputer Power; 2002.

92. Dierschke H. Pflanzensoziologie. Stuttgart: Ulmer; 1994.

93. Weber HE, Moravec J, Theurillat JP. International code of phytosociological nomenclature. 3rd edition. J Veg Sci. 2000;11(5):739-768. http://dx.doi. org/10.2307/3236580

94. Sîrbu C. Segetal vegetation from Cotnari, Iaşi and Huşi vineyards. Sci Ann Alexandru Ioan Cuza Univ Iasi. 2004;50:95-108.

95. Chytrý M, editor. Vegetace České republiky 2. Ruderální, plevelová, skalní a sutová vegetace. Prague: Academia; 2009.

96. Bagrikova NA. Antropotolerantnist ugrupovan ta strategia burianiv w agrocenoyah Krimu. Chernomorskij Bot Zurnal. 2010;6(4):468-474.

97. Ninot JM, Font X, Masalles RM, Vigo J. Syntaxonomic conspectus of the vegetation of Catalonia and Andorra. II. Ruderal communities. Acta Bot Barcinonensia. 2010;53:113-189.

98. Willner W. The association concept revisited. Phytocoenologia. 2006;36(1):67-76. http://dx.doi.org/10.1127/0340-269X/2006/0036-0067

99. Czerepanov SK. Plantae Vasculares URSS. Leningrad: Nauka; 1995.

100. Vasilchenko IT. Sornyje rastienia Tadżykistana. Moskwa-Leningrad: Izdatelstwo Akademii Nauk SSSR; 1953.

101. Nowak A, Nowak S. Zróżnicowanie i chorologia chwastów segetalnych w gradiencie wysokościowym gór Pamiro-Ałaju w Tadżykistanie. In: I ogólnopolska konferencja naukowa "Synantropizacja w dobie zmian różnorodności biologicznej”, Wrocław, Poland, 30 June-2 July; 2011. Wrocław: University of Wrocław; 2011.

102. Fried G, Petit S, Dessaint F, Reboud X. Arable weed decline in northern France: crop edges as refugia for weed conservation? Biol Conserv. 2009;142(1):238-243. http://dx.doi.org/10.1016/j.biocon.2008.09.029

103. Bergmeier E. Diversity of aestival plant communities of irrigated garden croplands in Cretan villages. Braunschweiger Geobot Arb. 2008;9:65-80.

104. Brandes D. Flora und Vegetation der Bahnhöfe Mitteleuropas. Phytocoenologia. 1983;11:31-115.

105. Brandes D. Eisenbahnanlagen als Untersuchungsgegenstand der Geobotanik. Tuexenia. 1993;13:415-444.

106. Brandes D. Zur Flora von Verkehrsanlagen in Magdeburg. Floristische Rundbriefe. 1993;27:50-54.

107. Čarni A, Mucina L. Vegetation of trampled soil dominated by C4 plants in Europe. J Veg Sci. 1998;9(1):45-56. http://dx.doi.org/10.2307/3237222

108. Kropáč Z. Segetal vegetation in the Czech Republic: synthesis and syntaxonomical revision. Preslia. 2006;78:123-209.

109. Borhidi A. Magyaroszág növénytársulásai. Budapest: Akadémiai Kiadó; 2003.

110. Němec R, Lososová Z, Dřevojan P, Žáková K. Synanthropic vegetation of the Eragrostion cilianensi-minoris alliance in the Czech Republic. Biologia (Bratisl.). 2011;66(6):1019-1026. http://dx.doi.org/10.2478/ s11756-011-0108-0

111. Bagrikova NA. Segetal communities of vineyards of Crimea. Ukr Phytosoc Coll Ser A. 1996;3:81-92.

112. Mitić B, Topić J, Ilijanić L, Jasprica N, Milović M, Ruščić M, et al. Kartiranje flore Dalmacije. Lipanj: Prioritetna područja: otok Pag, estuarij Krke, otok Vis i pučinski otoci, Pelješac i Mljet, tok Cetine. Zagreb: University of Zagreb; 2009.

113. Brullo S. L’Hordeion leporini in Sicilia. Arch Bot Biogeogr Ital. 1983;58:55-88. 114. Géhu JM, Biondi J, Géhu F. Les vegetations nitro-halophiles des falaises de Bomfacio (Corse). Acta Bot Barcinonensia. 1988;37:237-243.

115. Rivas-Martínez S, Fernández-González F, Loidi J, Lousa M, Penas A. Syntaxonomical checklist of vascular plant communities of Spain and Portugal to association level. Itinera Geobot. 2001;14:1-341. 